\title{
Responses of Capsicum annum (red pepper) to Fertilization Rates at Various Soil Moisture Conditions
}

\author{
Kang-Ho Jung, Yeon-Kyu Sonn*, Kyoung-hwa Han, and Yong-seon Zhang \\ Soil and Fertilizer Division, National Academy of Agricultural Science, Wanju, Rep. of Korea
}

(Received: September 23 2014, Revised: September 25 2014, Accepted: September 28 2014)

This research was performed to test the hypothesis that the optimal fertilization rate for red pepper is changed by soil moisture condition. The experiment was conducted in rainfall-intercepted fields in Suwon, South Korea from 2002 to 2003. Soil was inigated at 30, 50, or $80 \mathrm{kPa}$ of soil moisture tension at $20 \mathrm{~cm}$ soil depth in 2002 and 30, 50, 100, or $150 \mathrm{kPa}$ in 2003. For both years, fertilization was performed with four levels: none, $0.5,1$, and 1.5 times of the recommended $N, P$, and $K$ fertilization rate. The irrigation amount was the greatest at $30 \mathrm{kPa}$ inigation while the water use efficiency increased with decrease of inigation amount. The Irrigation amount was $508 \mathrm{~mm}$ at $30 \mathrm{kPa}$ inigation and ranged from $355 \mathrm{~mm}$ to $435 \mathrm{~mm}$ at $50 \mathrm{kPa}$ irigation. The maximum yield was found at $30 \mathrm{kPa}$ inigation and 1.5 times of the recommend fertilization rate in 2002 and 2003. The yield index of red pepper increased linearly with the fertilization rate at $30 \mathrm{kPa}$ which implied that excess imigation induced nutrient leaching and reduced nutrient availability. The maximum yield in $50 \mathrm{kPa}$ and $80 \mathrm{kPa}$ was found at the recommend fertilization rate while the yield decreased by fertilization at $100 \mathrm{kPa}$ and $150 \mathrm{kPa}$ inigation. It implies that reduction of fertilization is the feasible practice to mitigate drought stress in fields without stable inigation resources.

Key words: Red pepper, Soil moisture, Fertilization, Irrigation
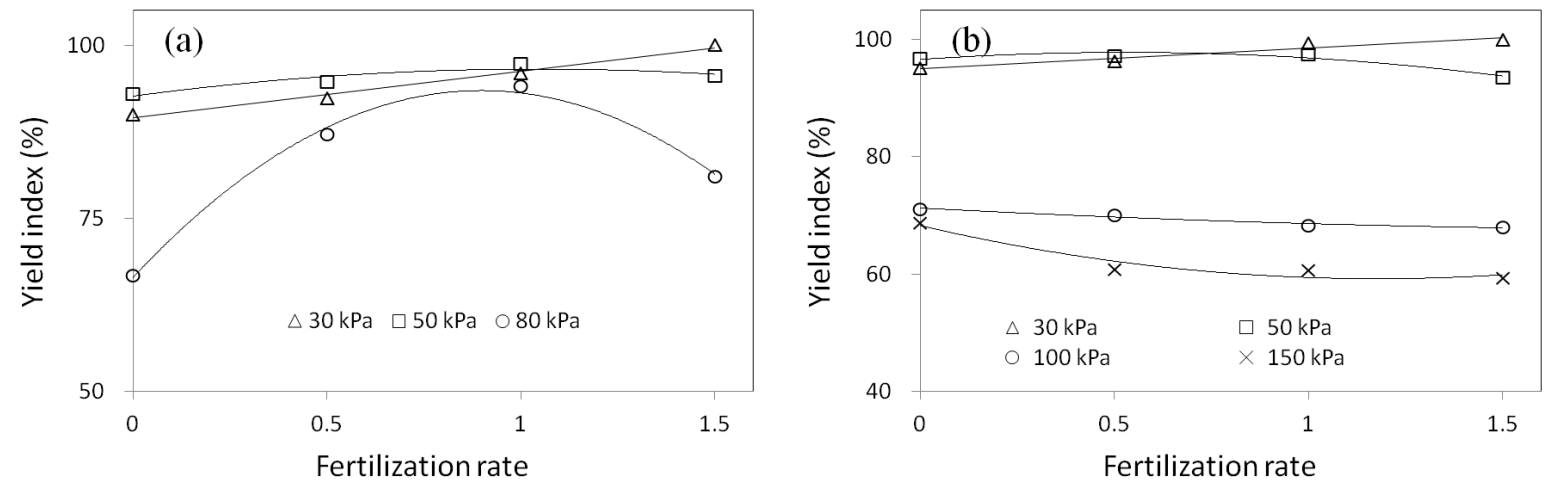

Yield of red pepper responding to fertilization rate at different soil moisture condition in 2002 (a) and 2003 (b).

*Corresponding author : Phone: +82632382425, Fax: +82632383822, E-mail: sonnyk@korea.kr

${ }^{\S}$ Acknowledgement: This research was supported by Rural Development Administration (PJ010058). 


\section{Introduction}

식물의 생육은 다양한 환경인자에 영향을 받는다. 토양 의 수분과 양분은 식물의 생육에 영향을 주는 대표적 환경 인자로서 안정적인 농산물 생산을 위해 관개, 비료 공급 등 의 영농활동을 통해 관리하고 있다. 토양의 수분과 양분은 식물 생육에 있어 때로는 상호 상승적인 효과를 나타내기도 하며 때로는 수분 또는 양분의 과부족이 다른 인자의 흡수 에 영향을 주기도 한다 (Eom et al., 1983; Kreuzwieser and Gessler, 2010).

뿌리를 통한 식물체의 양분 흡수는 토양 수분과 함께 질 량 유동의 형태로 이루어지거나 수용성 양분이 농도가 높은 토양용액에서 농도가 낮은 뿌리 쪽으로 확산함으로써 이루 어 진다 (Atwell et al., 1999). 따라서 수분이 적은 조건에 서는 양분의 유효도가 떨어지나 수분이 적절한 조건에서는 양분의 유효도가 증가한다 (Metwally and Pollad, 1959). 그 러나 수분이 너무 많아 침수된 상태에서는 양분 흡수가 감 소한다 (Lower and Orians, 2002). 강우가 과다하여 지표 유거와 지하 침투가 발생하는 경우에는 동반한 양분의 유실 로 양분 이용율이 감소할 수 있다 (Jung et al., 2009, Oh et al., 2002). 이는 양분의 효율적 관리를 위해 토양 수분을 적정하게 관리하여야 한다는 것을 암시한다.

토양 수분 조건은 식물체의 생장과 밀접한 관계가 있으 며 수분이 부족할 때 생장량 또는 수량이 급격히 감소한다 (Steduto et al., 2012). 식물체의 양분 흡수량은 생장량 및 수량에 따라 좌우되므로 수분이 적정한 조건과 건조한 조건 에서는 양분 요구량은 다를 수 있다. 더욱이 수분이 부족한 조건에서 추가적인 양분의 공급은 토양 용액의 삼투퍼텐셜 을 낮추어 수분 스트레스를 심화함으로써 식물의 생육을 악 화시킬 우려가 있다 (Muns, 2002). 따라서 작기 중에는 가 뭄의 정도를 판단하여 추비량을 조절할 필요가 있다.

고추 (Capsicum annum)는 고온성 작물로 열대, 아열대 에서는 여러 해 살이 식물이나 우리나라와 같은 조건에서는 한해 살이 식물로 재배된다. 고추는 천근성으로 토양이 건 조하면 수량이 낮아지므로 적정량의 규칙적인 관개가 필요 하다 (RDA, 2013). 관개에 의한 수량 증대는 관개시 양분 흡수량 증가를 의미하며 추가적인 양분 공급의 필요성을 내 포한다. 고추는 비료에 대해 민감한 작물은 아니나 전 생육 기간 양분이 지속적으로 유지되지 않으면 수량이 떨어지기 쉽다 (RDA, 2013). 이는 토양 수분의 관리 방식에 따라 고
추의 시비반응이 달라질 수 있음을 의미한다. 현재 밭작물 의 추천 시비량을 토양의 양분 함량을 검정하여 이를 기준 으로 평가하고 있으며 토양의 수분 조건은 고려되고 있지 않다 (RDA, 2014). 본 연구는 토양수분 조건에 따른 고추의 시비반응을 구명하고자 수행하였으며 이를 근거로 고추의 적정 양수분 관리방안을 도출하고자 하였다.

\section{Materials and Methods}

시험토양 및 포장조건 본 연구는 경기도 수원 소재 국립농업과학원 구내 포장에서 2002년과 2003년에 수행하 였으며 공시토양은 본량통이었다. 시험전 토양의 특성은 유 기물 함량이 적고 염류 농도가 낮아 비교적 비옥도가 불량 한 토양이었으며, 교환성 마그네슘과 칼륨의 함량이 적정범 위보다 낮았다 (Table 1) (RDA, 2014). 토성은 사양토였으며 포장용수량과 유효수분함량은 중량수분함량 기준 $17.3 \%, 12.1 \%$ 로 보수력이 약한 토양이었다. 토양 특성의 분석은 토양 및 식물체 분석법 (NIAST, 2000)에 준하였다. 인위적으로 토 양수분 조건을 조절하기 위하여 비가림 시설 $(20 \mathrm{mx} 33 \mathrm{~m})$ 에서 시험하였다.

재료 및 처리 토양수분은 토심 $20 \mathrm{~cm}$ 를 기준하여 특 정 토양수분 장력이 되면 관개하는 방식으로 설계하였으며 관개시점은 2002년 $30,50,80 \mathrm{kPa}$ 의 3수준을 처리하였으 나 $80 \mathrm{kPa}$ 과 $50 \mathrm{kPa}$ 관개간에 물소모량 차이가 적어 보다 건조한 조건의 결과를 얻기 위해 2003 년은 $30,50,100$, $150 \mathrm{kPa}$ 의 4수준을 처리하였다. 관개량은 $30,50 \mathrm{kPa}$ 의 경 우 $20 \mathrm{~cm}$ 에서 관개 후 토양 수분이 $10 \mathrm{kPa}$ 이 되는 것을 목 표로 하여 설정하였으며, $80 \mathrm{kPa}$ 이상에서는 포장 용수량 을 목표로 하여 설정하였다. 관개는 점적관개를 이용하였 다. 시비수준은 2002년과 2003년 모두 질소, 인산, 칼리를 대상으로 검정시비량의 $0,0.5,1,1.5$ 배를 처리하였다. 검 정시비량은 질소 $190 \mathrm{~kg} \mathrm{ha}{ }^{-1}$, 인산 $160 \mathrm{~kg} \mathrm{ha}$, 칼리 262 $\mathrm{kg} \mathrm{ha}{ }^{-1}$ 이었다. 비종은 질소, 인산, 칼리 를 대상으로 요소, 용과린, 염화칼륨을 선택하였으며, 밑거름과 웃거름의 비율 은 작물별 시비처방 기준에 준하였다 (RDA, 2014). 시험구 는 토양 수분 처리구를 추구로 시비처리구를 세구로 배치하 였다. 토양 수분 처리구는 2 반복이었으며, 시비처리구는 4 반복을 두었다. 이랑폭은 $150 \mathrm{~cm}$ 로 하여 두줄 심기를 하였 으며 주간은 $75 \mathrm{~cm} \mathrm{x} 45 \mathrm{~cm}$ 로 하였다. 정식은 5 월 1주에 하

Table 1. Physicochemical properties of studied soil.

\begin{tabular}{|c|c|c|c|c|c|c|c|c|c|c|c|}
\hline \multirow{2}{*}{$\mathrm{pH}$} & \multirow[t]{2}{*}{$\mathrm{EC}$} & \multirow{2}{*}{$\begin{array}{c}\text { Organic } \\
\text { matter }\end{array}$} & \multirow[t]{2}{*}{$\mathrm{Av} \cdot \mathrm{P}_{2} \mathrm{O}_{5}$} & \multicolumn{4}{|c|}{ Exchangeable cation } & \multirow{2}{*}{$\begin{array}{l}\text { Texture } \\
\text { (USDA) }\end{array}$} & \multicolumn{3}{|c|}{ Soil moisture characteristics } \\
\hline & & & & $\mathrm{Ca}$ & $\mathrm{Mg}$ & $\mathrm{K}$ & $\mathrm{Na}$ & & $10 \mathrm{kPa}$ & $30 \mathrm{kPa} \quad 50 \mathrm{kPa} \quad 100 \mathrm{kPa}$ & $1500 \mathrm{kPa}$ \\
\hline & $\mathrm{dS} \mathrm{m}^{-1}$ & $\mathrm{~g} \mathrm{~kg}^{-1}$ & $\mathrm{mg} \mathrm{kg}{ }^{-1}$ & 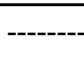 & $\mathrm{cmo}$ & $\mathrm{kg}^{-1}$ & $\begin{array}{c}---- \\
---1\end{array}$ & & 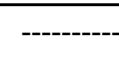 & w/w, \% - & ------------ \\
\hline 6.3 & 0.4 & 11.8 & 267 & 5.9 & 1.4 & 0.4 & 0.27 & SL & 22.3 & 17.7 & 5.2 \\
\hline
\end{tabular}


였으며, 수확은 8 9월에 4회 (2002년), 3회 (2003년)하였으 며, 최종 수확은 9월 4주에 하였다.

토양 및 식물체 분석 토양 수분 장력은 2002년은 토 양 수분 장력계 (Tensiometer, Soil moisture, USA)를 20 $\mathrm{cm}$ 깊이에 매설하여 1 3일 간격으로 측정하였으며 2003년 은 $30 \mathrm{kPa}$ 과 $50 \mathrm{kPa}$ 관개구는 2002년과 동일한 방법으로, 100 $\mathrm{kPa}$ 과 $150 \mathrm{kPa}$ 관개구는 토양 수분 장력 센서 (Watermark, Spectrum, US)를 이용하여 측정하였다. 관개량은 수도용 유 량계를 이용하여 측정하였다. 수확은 8월과 9월에 3회 (2003 년) 또는 4회 (2002년)에 걸쳐 실시하였으며 숙과중을 기준 으로 하였다. 수량지수는 최대수량이 기록된 $30 \mathrm{kPa}$ 관개, 검정시비의 1.5 배구 수량을 최대치 (100)으로 하여 계산하 였다. 물이용 효율은 관개량에 대한 수량 (숙과중)의 비율로 계산하였다. 고추의 수분민감도는 아래의 식으로 계산하였 다 (Steduto et al., 2012).

$$
\left(1-\frac{\mathrm{Y}_{\mathrm{a}}}{\mathrm{Y}_{\mathrm{m}}}\right)=\mathrm{K}_{\mathrm{y}}\left(1-\frac{\mathrm{ET}_{\mathrm{a}}}{\mathrm{ET}_{\mathrm{m}}}\right)
$$

위의 식에서 $\mathrm{Y}_{\mathrm{a}}$ 와 $\mathrm{ET}_{\mathrm{a}}$ 는 실제 조건에서의 수량과 증발산 량이며, $\mathrm{Y}_{\mathrm{m}}$ 과 $\mathrm{ET}_{\mathrm{m}}$ 은 최대 수량과 그 때의 증발산량이다. 작 물의 증발산량은 비닐 멀칭시 점적관개의 관개효율을 $100 \%$ 로 가정하고 관개량으로 대체하였다. $30 \mathrm{kPa}$ 관개는 배수 가 예상되는 약간 과습한 조건이므로 이 처리의 결과는 수
분 민감도 분석에서 제외하였다. 식물체는 줄기, 잎, 과실로 나누어 건중량, 질소, 인, 칼륨의 함량을 분석하였다. 식물체 의 분석은 토양 및 식물체 분석법 (NIAST, 2000)에 준하였다.

통계분석 토양수분 조건과 시비수준의 식물 생육과 수 량에 대한 영향은 분산분석 (ANOVA)을 통해 검정하였다. 수량에 대한 관개량의 영향은 비선형 회귀분석을 통해 분석 하였고, 토양수분 조건별 시비반응은 수량지수를 시비수준 에 따라 1 차 또는 2 차식으로 분석하였다. 유의성은 $\alpha=0.05$ 를 기준으로 검정하였으며 통계프로그램은 SAS 9.2 (SAS Institute, US)를 이용하였다.

\section{Results}

토양수분 조건에 대한 고추의 생육반응 $30 \mathrm{kPa}$ 관 개시 기준 증발산량이 높은 6월에는 평균 2일 간격, 7-9월 에는 평균 3 일 간격으로 관수하였으며, $50 \mathrm{kPa}$ 관개시는 4-6일 간격으로 관수하였다 (Fig. 1). 2002년 $80 \mathrm{kPa}$ 관개 시는 6-7월 6일 간격, 8-9월 10일 간격으로 관수하였으며 2003년 $100 \mathrm{kPa}$ 이상에서 관개시 월 2 4회 정도 관수하였 다. 2002년, 2003년 모두 $30 \mathrm{kPa}$ 관개시 가장 많은 관개량 이 소모되었다 (Table 2). 높은 토양 수분 장력에서 관개시 관개량이 감소하였으나 물이용 효율은 증가하였다. $30 \mathrm{kPa}$ 관개시 2002년과 2003년 관개량, 수량, 물이용 효율이 유사 하였다. $50 \mathrm{kPa}$ 관개시 2002년과 2003년 유사한 수량을 나
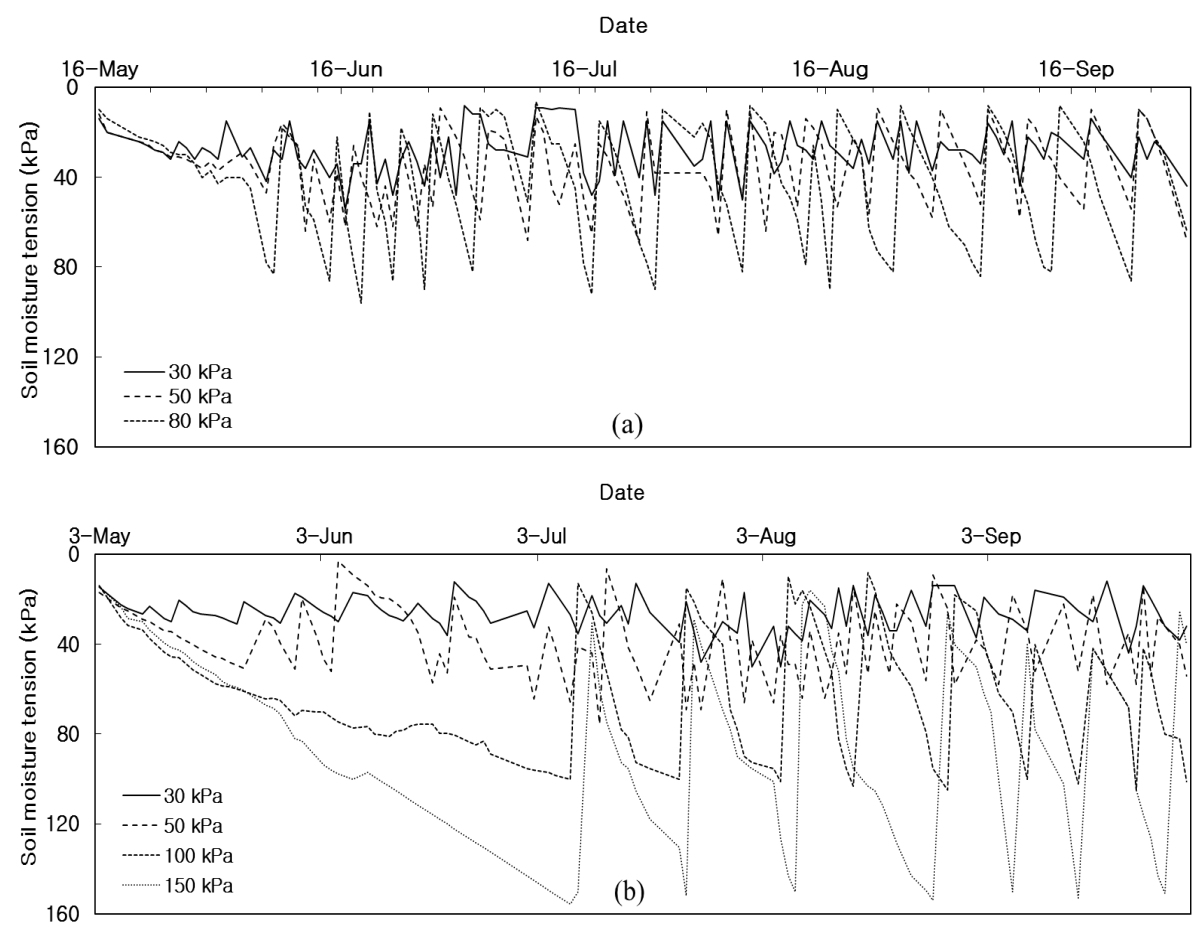

Fig. 1. Changes in soil moisture tension with inigation methods in Suwon in 2002 (a) and in 2003(b). Water was added when soil moisture tension reached at specific soil moisture tensions. 
타내었으나 2003년 적은 양의 물이 관수되어 물이용 효율 이 높았다. 검정시비량으로 양분관리시 $30 \mathrm{kPa}$ 관개와 50 $\mathrm{kPa}$ 관개에서 가장 높은 수량지수를 보였으나 관개량은 30 $\mathrm{kPa}$ 관개에 비해 $50 \mathrm{kPa}$ 관개시 $14 \sim 30 \%$ 절감되었다. 80 $\mathrm{kPa}$ 이하에서 관개시 $30 \mathrm{kPa}$ 이나 $50 \mathrm{kPa}$ 관개에 비해 유의 하게 수량지수가 감소하였다 (Fig. 3). 고추의 수량은 관개 량 감소에 따라 지수적으로 감소하였다 (Fig. 2(a)). Fig. 2(a)에서 이상치로 보이는 자료는 2002 년 $80 \mathrm{kPa}$ 관개시 무 비구의 수량이다. 관개량을 이용한 수량지수 회귀식에 따르 면 최대수량의 $80 \%$ 이상을 수확하기 위해서 $245 \mathrm{~mm}$ 이상 의 물이 공급되어야 하며, 최대수량의 $50 \%$ 이상을 수확하기 위해서는 $120 \mathrm{~mm}$ 이상의 물이 공급되어야 하는 것으로 나 타났다. 고추의 수분 부족에 대한 민감도는 0.61 로 평가되 었다 (Fig. 2(b)).

Table 2. Inigation amount and water use efficiency of red pepper with inigation methods and fertilization rate in Suwon in 2002 and 2003.

\begin{tabular}{cccccc}
\hline \hline Year & ${ }^{1}$ Soil moisture tension & Irrigation volume & ${ }^{2}$ Yield & ${ }^{3}$ Yield index & Water use efficiency \\
\hline \multirow{2}{*}{2002} & $\mathrm{kPa}$ & $\mathrm{mm}$ & $\mathrm{Mg} \mathrm{ha}{ }^{-1}$ & $\%$ & $\mathrm{~g} \mathrm{~kg}^{-1}$ \\
& 30 & $508 \mathrm{a}$ & $18.8 \mathrm{a}$ & 96.0 & $3.70 \mathrm{c}$ \\
& 50 & $435 \mathrm{~b}$ & $19.0 \mathrm{a}$ & 97.3 & $4.38 \mathrm{~b}$ \\
2003 & 80 & $308 \mathrm{c}$ & $18.4 \mathrm{~b}$ & 94.1 & $5.97 \mathrm{a}$ \\
& 30 & $508 \mathrm{a}$ & $21.5 \mathrm{a}$ & 99.4 & $3.96 \mathrm{~d}$ \\
& 50 & $355 \mathrm{~b}$ & $20.9 \mathrm{a}$ & 97.5 & $5.88 \mathrm{c}$ \\
& 100 & $162 \mathrm{c}$ & $14.7 \mathrm{~b}$ & 68.3 & $9.02 \mathrm{a}$ \\
\hline
\end{tabular}

${ }^{1}$ Irrigation was applied at proposed soil moisture tension.

${ }^{2}$ Planting density was 20,000 each ha $^{-1}$

${ }^{3}$ Yield index was calculated as a yield of each treatment divided by the maximum yield found at $30 \mathrm{kPa}$ irrigation and 1.5 times of recommended fertilization rate in each year.
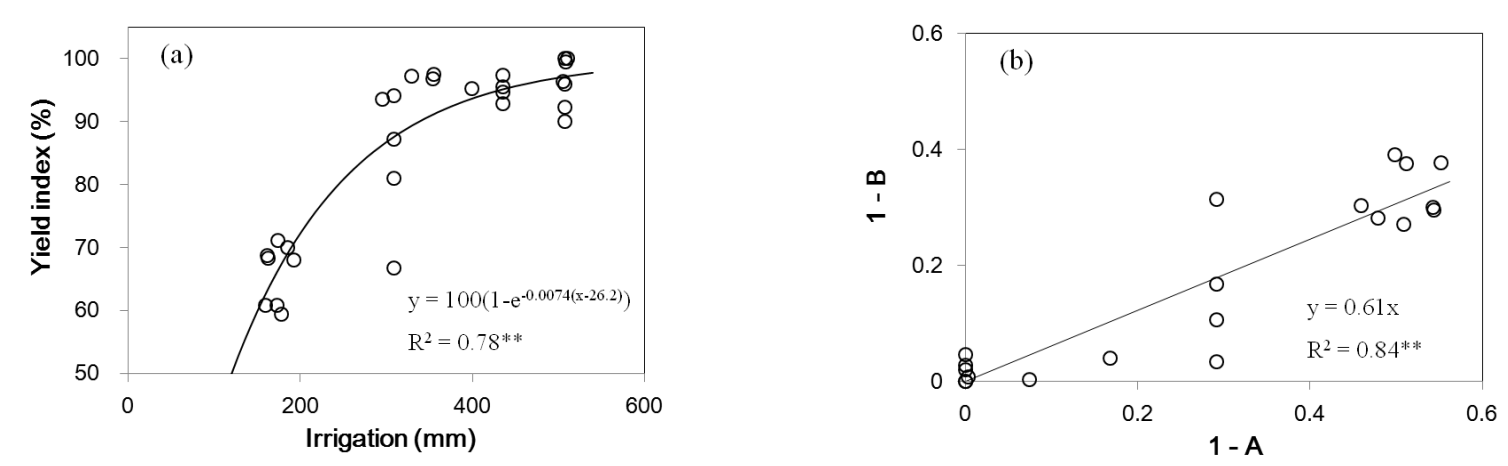

Fig. 2. Yield responses of red pepper to inigation amount (a) and soil water deficit (b). $A$ is a ratio of actual evapotranspiration to maximum evapotranspiration and $B$ is a ratio of actual yield to maximum yield.
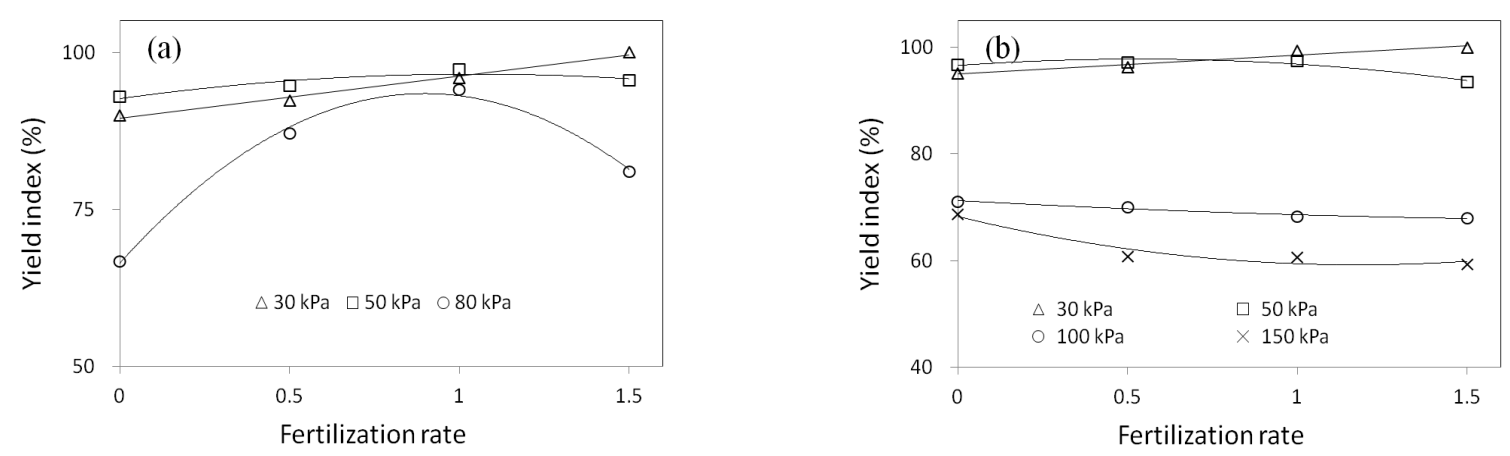

Fig. 3. Yield of red pepper responding to fertilization rate at different soil moisture condition in 2002 (a) and 2003 (b). Soil moisture condition was controlled to imigate at the proposed soil moisture tension and fertilization was performed with $0,0.5$, 1 , and 1.5 times of the recommended fertilization rate based on soil testing data. Yield index was calculated as a yield of each treatment divided by the maximum yield found at $30 \mathrm{kPa}$ imigation and 1.5 times of recommended fertilization rate in each year. 

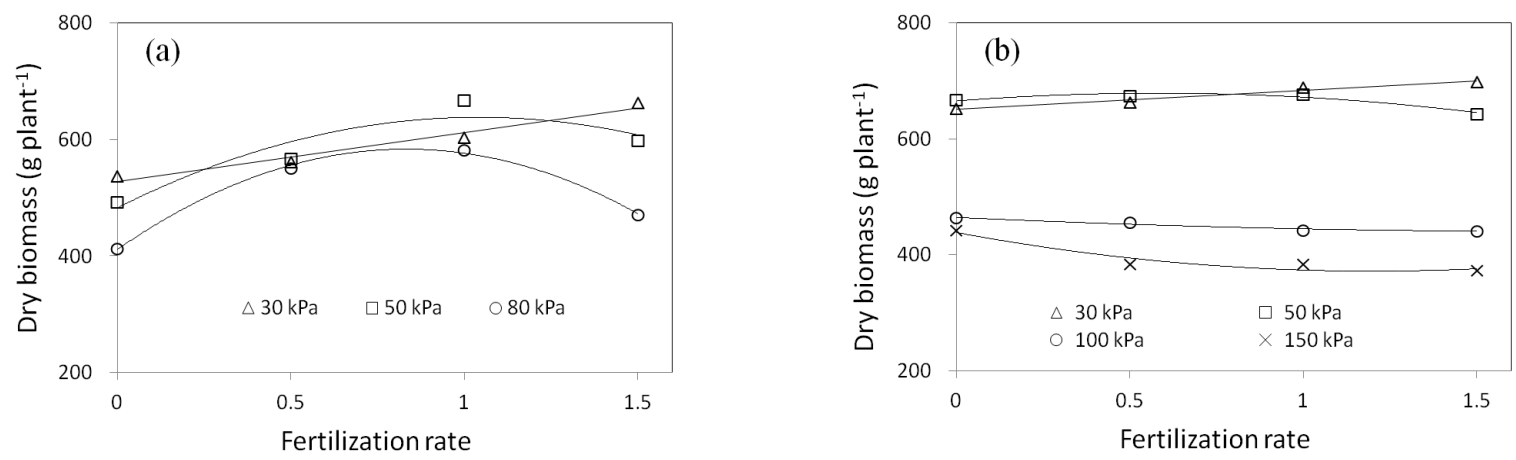

Fig. 4. Dry biomass of red pepper as summation of stem, leaves, and fruits responding to fertilization rate at different soil moisture condition in 2002 (a) and 2003 (b). Soil moisture condition was controlled to inigate at the proposed soil moisture tension and fertilization was performed with $0,0.5,1$, and 1.5 times of the recommended fertilization rate based on soil testing data.

Table 3. Nutrient uptake of stem, leaf, and fruit of red pepper. Soil moisture condition was controlled to inigate at the proposed soil moisture tension and fertilization was performed with $0,0.5,1$, and 1.5 times of the recommended fertilization rate based on soil testing data.

\begin{tabular}{|c|c|c|c|c|c|c|c|c|c|c|c|}
\hline \multirow{2}{*}{ Year } & \multirow{2}{*}{ Irrigation } & \multirow{2}{*}{ Fertilization rate } & \multicolumn{3}{|c|}{$\mathrm{N}$} & \multicolumn{3}{|c|}{$\mathrm{P}$} & \multicolumn{3}{|c|}{$\mathrm{K}$} \\
\hline & & & Stem & Leaf & Fruit & Stem & Leaf & Fruit & Stem & Leaf & Fruit \\
\hline & & & -ב--- & $\mathrm{g} \mathrm{kg}^{-1}$ & ------ & ------- & $\mathrm{g} \mathrm{kg}^{-1}$ & ------ & ------- & $\mathrm{g} \mathrm{kg}^{-1}$ & 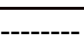 \\
\hline \multirow[t]{12}{*}{2002} & $30 \mathrm{kPa}$ & 0 & 8.6 & 25.6 & 10.0 & 0.9 & 2.8 & 2.9 & 11.8 & 32.1 & 26.2 \\
\hline & & 0.5 & 7.8 & 25.8 & 9.7 & 0.9 & 2.9 & 2.9 & 18.4 & 39.2 & 29.3 \\
\hline & & 1 & 7.0 & 25.5 & 9.5 & 1.0 & 2.8 & 2.8 & 16.7 & 36.1 & 26.2 \\
\hline & & 1.5 & 8.3 & 24.9 & 9.5 & 1.0 & 2.5 & 2.7 & 14.9 & 27.8 & 24.0 \\
\hline & $50 \mathrm{kPa}$ & 0 & 8.5 & 21.8 & 10.7 & 1.1 & 2.8 & 2.8 & 17.8 & 24.4 & 22.3 \\
\hline & & 0.5 & 6.6 & 26.0 & 10.2 & 1.0 & 3.3 & 2.9 & 12.9 & 34.2 & 25.0 \\
\hline & & 1 & 9.0 & 26.7 & 10.1 & 0.7 & 2.7 & 2.8 & 18.4 & 28.7 & 23.5 \\
\hline & & 1.5 & 7.8 & 28.0 & 10.0 & 0.9 & 2.9 & 2.7 & 14.9 & 37.3 & 23.5 \\
\hline & $80 \mathrm{kPa}$ & 0 & 7.6 & 24.1 & 9.2 & 1.5 & 3.4 & 2.7 & 15.0 & 26.7 & 24.8 \\
\hline & & 0.5 & 8.3 & 21.2 & 11.0 & 1.2 & 2.4 & 2.7 & 16.9 & 26.9 & 22.8 \\
\hline & & 1 & 7.6 & 24.1 & 10.1 & 1.5 & 3.4 & 2.8 & 15.0 & 26.7 & 27.1 \\
\hline & & 1.5 & 6.5 & 26.7 & 10.7 & 1.1 & 3.0 & 2.7 & 15.3 & 40.2 & 24.9 \\
\hline \multirow[t]{16}{*}{2003} & $30 \mathrm{kPa}$ & 0 & 7.8 & 25.6 & 9.7 & 0.9 & 2.8 & 2.9 & 15.6 & 35.8 & 27.3 \\
\hline & & 0.5 & 7.7 & 25.4 & 9.6 & 1.0 & 2.7 & 2.8 & 16.7 & 34.4 & 26.5 \\
\hline & & 1 & 7.9 & 24.1 & 9.9 & 1.0 & 2.7 & 2.8 & 16.5 & 29.4 & 24.2 \\
\hline & & 1.5 & 7.8 & 24.2 & 10.1 & 1.0 & 2.8 & 2.8 & 15.2 & 28.8 & 23.8 \\
\hline & $50 \mathrm{kPa}$ & 0 & 8.0 & 24.8 & 10.3 & 1.0 & 2.9 & 2.8 & 16.4 & 29.1 & 23.6 \\
\hline & & 0.5 & 7.8 & 26.9 & 10.1 & 0.9 & 3.0 & 2.8 & 15.4 & 33.4 & 24.0 \\
\hline & & 1 & 8.1 & 26.3 & 9.8 & 1.0 & 3.0 & 2.7 & 16.1 & 30.9 & 23.9 \\
\hline & & 1.5 & 7.9 & 24.4 & 10.1 & 1.2 & 2.9 & 2.7 & 15.6 & 30.3 & 23.7 \\
\hline & $100 \mathrm{kPa}$ & 0 & 7.5 & 24.0 & 10.3 & 1.3 & 3.1 & 2.7 & 15.5 & 30.1 & 24.9 \\
\hline & & 0.5 & 7.6 & 24.4 & 10.4 & 1.4 & 3.1 & 2.8 & 15.7 & 32.4 & 25.5 \\
\hline & & 1 & 7.4 & 25.5 & 10.0 & 1.3 & 3.2 & 2.8 & 15.7 & 34.2 & 26.5 \\
\hline & & 1.5 & 7.5 & 25.5 & 10.0 & 1.3 & 3.1 & 2.8 & 16.0 & 34.9 & 25.7 \\
\hline & $150 \mathrm{kPa}$ & 0 & 7.8 & 24.8 & 9.8 & 1.3 & 3.1 & 2.8 & 16.0 & 32.1 & 25.4 \\
\hline & & 0.5 & 7.9 & 24.6 & 10.0 & 1.3 & 3.2 & 2.8 & 16.2 & 30.4 & 24.5 \\
\hline & & 1 & 7.9 & 25.0 & 10.1 & 1.3 & 3.1 & 2.8 & 15.9 & 30.2 & 23.9 \\
\hline & & 1.5 & 7.9 & 25.6 & 10.1 & 1.3 & 3.2 & 2.8 & 15.8 & 30.5 & 23.8 \\
\hline
\end{tabular}


토양수분 조건별 시비수준에 따른 생육반응 2002 년과 2003년 모두 최대 수량은 $30 \mathrm{kPa}$ 관개시 검정시비 1.5 배구에서 나타났다 (Fig. 3). 시비수준에 따른 고추의 수량 은 $30 \mathrm{kPa}$ 관개시 2002년과 2003년 모두 검정시비량의 1.5 배까지 직선적으로 증가하였다. $30 \mathrm{kPa}$ 관개 1.5 배 시비의 수량은 2002년 $1957 \mathrm{~kg} \mathrm{ha}^{-1}$, 2003년 $2145 \mathrm{~kg} \mathrm{ha}^{-1}$ 이었다. 이에 반해 $50 \mathrm{kPa}$ 관개시와 $80 \mathrm{kPa}$ 관개시는 시비수준에 따른 고추의 수량반응이 2 차식의 형태를 나타냈다. 2 차식을 기준으로 할 때 2002 년 $50 \mathrm{kPa}$ 관개시는 검정시비량, 80 $\mathrm{kPa}$ 관개시 검정시비량의 0.8 배에서 최대수량이 나타났으 며, 2003 년 $50 \mathrm{kPa}$ 관개시는 검정시비량의 0.5 배에서 최대 수량이 나타났다. 그러나 2003년의 경우 $50 \mathrm{kPa}$ 관개시 검 정시비량의 $0,0.5,1$ 배구의 사이에서 수량의 유의차는 발 견되지 않았다. $100 \mathrm{kPa}$ 이상에서 관개시 수량은 시비량 증 가에 따라 감소하는 것으로 나타났다. 건중은 수량과 유사
한 경향을 나타내었으나 2002년의 경우 토양 수분 처리간 차이가 없었다 (Fig. 4). 식물체 뿌리, 줄기, 잎, 과실의 양 분함량은 처리간의 유의한 차이가 없었으며 기관에 따라 양 분의 함량이 달랐다 ( $\mathrm{p}<0.001)$ (Table 3$)$. 잎의 평균 질소함 량은 $25.1 \mathrm{~g} \mathrm{~kg}^{-1}$ 였으며, 과실과 줄기의 질소 함량은 각각 $10.0,7.8 \mathrm{~g} \mathrm{~kg}^{-1}$ 이었다. 인의 경우 과실과 잎에서의 함량이 $2.9 \mathrm{~g} \mathrm{~kg}^{-1}$ 내외로 유사하였으나 줄기의 인 함량은 $1.1 \mathrm{~g}$ $\mathrm{kg}^{-1}$ 이었다. 칼륨 함량은 질소 함량과 마찬가지로 잎 (31.7 $\left.\mathrm{g} \mathrm{kg}^{-1}\right)$, 과실 $\left(24.9 \mathrm{~g} \mathrm{~kg}^{-1}\right)$, 줄기 $\left(15.8 \mathrm{~g} \mathrm{~kg}^{-1}\right)$ 의 순으로 나 타났으나 기관간 차이는 질소보다 작았다. 단위면적당 질소 흡수량은 재식밀도 20,000 주 $\mathrm{ha}^{-1}$ 를 기준할 때 최대수량을 기록한 $30 \mathrm{kPa}$ 관개시 검정시비의 1.5 배구에서 2002 년 30.5 $\mathrm{kg} \mathrm{ha}^{-1}, 2003$ 년 $39.2 \mathrm{~kg} \mathrm{ha}$ 이었다 (Fig. 5). 수량지수가 60 내외였던 $150 \mathrm{kPa}$ 관개시 질소흡수량은 $144 \sim 146 \mathrm{~kg} \mathrm{ha}^{-1}$ 로 나타났다. 단위면적당 인 흡수량은 때 최대수량을 기록
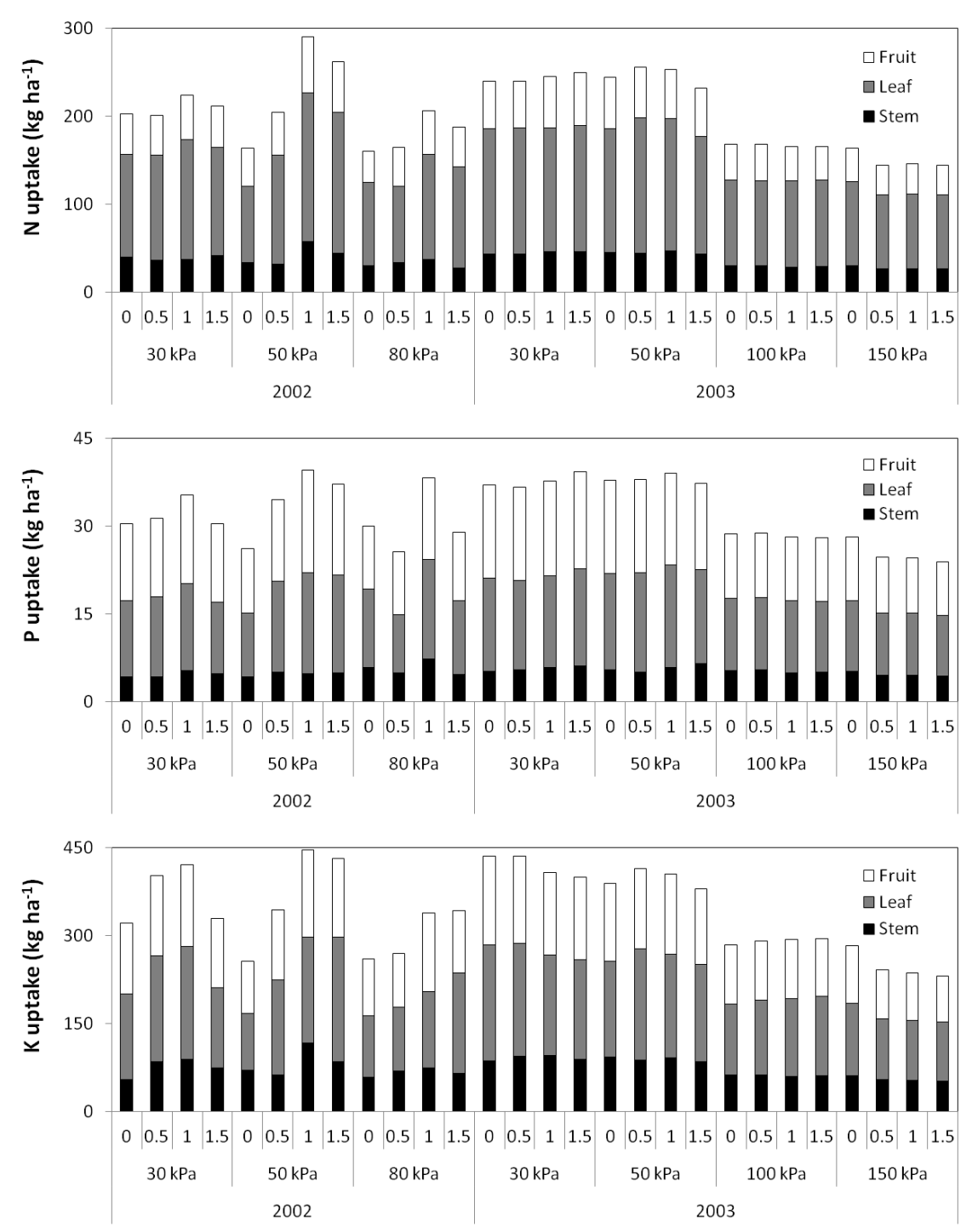

Fig. 5. Nitrogen (N), phosphor (P), and potassium (K) uptake responding to fertilization rate at different soil moisture condition. Soil moisture condition was controlled to inigate at the proposed soil moisture tension and fertilization was performed with $0,0.5$, 1, and 1.5 times of the recommended fertilization rate based on soil testing data. Planting density was 20,000 each ha $^{-1}$. 
한 $30 \mathrm{kPa}$ 관개시 검정시비의 1.5 배구에서 2002 년 $220 \mathrm{~kg}$ $\mathrm{ha}^{-1}, 2003$ 년 $249 \mathrm{~kg} \mathrm{ha}{ }^{-1}$ 이었다. 단위면적당 칼륨 흡수량 은 때 최대수량을 기록한 $30 \mathrm{kPa}$ 관개시 검정시비의 1.5 배 구에서 2002년 $330 \mathrm{~kg} \mathrm{ha}^{-1}$, 2003년 $399 \mathrm{~kg} \mathrm{ha}^{-1}$ 이었다. 최 대수량이 $30 \mathrm{kPa}$ 관개시 1.5 배구에서 나온 것과는 달리 양 분 흡수량은 $50 \mathrm{kPa}$ 관개시 검정시비구에서 최대치를 나타 냈으며, 특히 잎과 줄기의 양분함량이 높았다.

\section{Discussion}

과다 관개와 양분 효율 $30 \mathrm{kPa}$ 관개시 고추의 수량반 응은 시비량 증가에 따라 직선적으로 증가하는 것으로 나타 났다. 건중 역시 수량과 마찬가지로 시비량 증가에 따라 직 선적으로 증가하였다. 이는 두 가지 상반된 방향으로 해석 이 가능하다. 한 가지는 토양 수분을 충분한 상태로 유지할 때는 검정시비량 이상의 양분을 공급함으로써 생산량이 높 일 수 있다는 해석이며, 다른 하나는 관개량이 많을 때는 투 입된 양분의 이용율이 낮아져 더 많은 양분을 공급하여야 한다는 해석이다. 수량을 근거로 하면 전자의 해석이 가능 할 수도 있으나 $30 \mathrm{kPa}$ 관개 검정시비의 1.5 배구에 비해 50 $\mathrm{kPa}$ 관개 검정시비구와 1.5 배구의 양분흡수량이 높다는 결 과는 후자의 방향으로 해석할 필요가 있음을 의미한다 (Fig. 5). $30 \mathrm{kPa}$ 관개의 경우 $50 \mathrm{kPa}$ 관개에 비해 검정시비구 기 준 2002년 $73 \mathrm{~mm}, 2003$ 년 $153 \mathrm{~mm}$ 의 물이 추가로 공급되 었으나 수량, 건중, 양분흡수량의 유의적인 증가가 없었으 며 (Table 2, Fig 2 4), 이는 추가된 물이 고추 생장을 위해 사용되었기 보다 지하로 투수되면서 양분 용탈을 야기했음 을 함축한다. 우리나라에서 고추의 최대 증발산량은 $350 \mathrm{~mm}$ (Song et al., 1992)로 보고되었으며, Oh and Cho (2001)는 고추 재배 적정관개시 관개량을 $395 \mathrm{~mm}$ 로 보고하였다. 이 는 본 연구에서 $50 \mathrm{kPa}$ 관개시 관개량과 유사한 값이며 30 $\mathrm{kPa}$ 관개시 관개량보다 $100 \mathrm{~mm}$ 이상 낮은 값이다. 따라서 $30 \mathrm{kPa}$ 관개의 경우 상당한 양의 물이 증발산으로 소모되지 않고 근권 아래로 배수되었을 가능성이 있다. 이로 미루어 볼 때 $30 \mathrm{kPa}$ 관개시 직선적으로 증가한 시비반응은 잉여의 관개수에 의해 양분이용율이 낮아진 결과로 해석하는 것이 합당하다. 우리나라에서 시설 재배의 증가와 더불어 관개 시설이 늘어나면서 과다 관개에 대한 피해가 우려되고 있 다. 과다 관개는 기상율을 감소시켜 뿌리 호흡을 저해할 뿐 만 아니라 (Hillel, 1998) 용탈에 의해 양분 이용율이 낮아지 기 때문에 필연적으로 과다 시비를 유발하게 된다 (Jung et al., 2009; Oh et al., 2002). 점적관개시 뿌리는 습윤권역 에 분포하나 소비되지 못한 양분은 반타원형의 습윤권역 외 부, 특히 지표에 집적되기 때문에 염류 집적을 가속화하는 원인이 된다 (Ryu et al., 2001). 이는 토양 수분 장력을 낮 게 유지하고자 할 때 관개수가 근권 이내에 분포할 수 있도
록 1 회 관개량을 줄여야 염류집적을 최소화할 수 있다는 것 을 의미하나 적은 양을 자주 관개할 경우 뿌리의 분포가 얕 은 토심에 집중된다는 한계가 있다 (Bhat, 1983; Neilson et al., 1997),

과다 시비와 수분 퍼텐셜 감소 본 연구결과 $50 \mathrm{kPa}$ 또는 그보다 높은 조건에서 관개시 적정 수준 이상의 양분 공급은 유의한 수량과 생육의 감소를 유발하였다 (Fig. 3, Fig. 4). 특정 물질 과다에 의한 생육의 장애는 알루미늄 독 성, 망간 독성 등 독성 장애와 알루미늄 과다에 의한 칼슘 흡수 장애와 같은 결핍 장애가 있다 (Clark and Baligar, 2000). 본 연구에서 투입된 비료는 요소, 용과린, 염화칼륨 으로 적정보다 과다하게 공급되었다 하더라도 독성 또는 결 핍 장애를 유발할 만한 성분을 함유하고 있지 않았다. 양분 과다에 의한 다른 측면의 생육 장애는 수분 흡수 저해이다 (Atwell, 1998). 식물체가 수분 흡수를 하는 주요 구동력은 증산에 의해 발생하는 음압과 토양과 식물체 사이의 삼투압 구배이다. 증산이 활발하고 토양 수분 장력이 낮을 때는 증 산으로 인한 음압이 수분 흡수의 주요 구동력으로 작용하며 이 때 수분은 뿌리털의 투수성 세포벽을 통해 뿌리로 들어 와 세포간극을 통해 이동 (apoplastic pathway)하여 물관 부에 도달하는 것을 주된 경로로 한다. 반면 증산이 적고 토양 수분 장력이 높을 경우에는 삼투압 구배가 수분흡수 의 주요 구동력이 되며 투수성 세포벽을 통과한 물이 삼투 현상에 의해 세포막을 투과한 후 원형질연락사를 통한 이동 (symplastic pathway) 또는 세포를 횡단하는 이동 (transcelluar pathway)을 통해 물관부에 도달한다. 이는 토양 용액 중 전 해질 농도 증가에 따른 삼투 퍼텐셜 감소가 토양 수분 장력 이 낮을 때 (=매트릭 퍼텐셜이 높을 때=수분함량이 많을 때)에 비해 토양 수분 장력이 높을 때 (=매트릭 퍼텐셜이 낮 을 때=수분함량이 적을 때) 식물체의 수분 흡수에 더 큰 영 향을 준다는 것을 의미한다.

본 연구 결과에 기반하면 토양 수분 장력이 $100 \mathrm{kPa}$ 이하 로 떨어질 수 있는 조건, 즉, 약 10 일 이상 무강우/무관개가 반복되는 상황에서 추비를 공급하면 한발시 수분 흡수 장애 를 심화할 수 있다. 고추의 경우 3 회 웃거름을 주도록 추천 하고 있으나 (RDA, 2014) 10일 이상 무강우/무관개가 계속 되는 조건이라면 추비를 주지 않는 것이 나을 수 있다. 우리 나라의 검정시비량을 산정시 토양 수분 관리는 고려되지 않 고 있다 (RDA, 2014). 토양 수분 장력이 상대적으로 높게 유지되는 환경, 즉, 보수력이 낮아 상대적으로 쉽게 건조하 는 사질 토양, 관개시설이 미비한 농경지에서는 과다시비를 할 경우 다른 농경지에 비해 한발시 피해가 심화될 우려가 있다. 더구나 우리나라의 한발 피해는 봄, 가을 주로 발생하 며, 세계적인 기후변화와 함께 증가하는 추세이다 (Lee and $\mathrm{Kim}, 2011)$. 따라서 안정적인 관개수원이 확보되지 않은 농 
경지에서는 기준보다 적은 양의 양분을 공급하는 것이 한발 피해를 줄이는 방법이 될 수 있다.

\section{Conclusions}

고추의 시비반응은 토양수분 조건에 따라 다르게 나타났 다. $30 \mathrm{kPa}$ 이하로 토양을 약간 과습하게 유지할 때는 물소 모량 이상의 물이 투입되어 양분의 용탈 또는 지표 습윤전 면에의 집적이 우려되었으며 이로 인해 검정시비를 초과하 여 시비할 때 최대 수량이 수확되었다. 이에 반해 $50 \mathrm{kPa}$ 과 $80 \mathrm{kPa}$ 관개시 검정시비량 이상으로 양분공급시 수량 증가 가 정체되거나 감소되었다. $100 \mathrm{kPa}$ 과 $150 \mathrm{kPa}$ 관개시 토 양이 건조하게 유지됨에 따라 양분의 공급이 수량 증가에 기여하지 못하고 오히려 삼투 퍼텐셜 감소에 따라 한발을 심화시켜 수량 저감을 유발하였다. 이는 토양 수분 부족이 우려되는 농경지 또는 한발이 진행되는 조건에 대해 시비량 을 감축할 필요를 의미하였다.

\section{References}

Atwell, B.J., P.E. Kriedeman, and C.G.N. Turnbull. 1999. Plants in action. Macmillan Education Australia Pty Ltd, Melbourne, Australia.

Bhat, K.K. S. 1983. Nutrient inflows into apple roots. Plant and Soil. 71:371-380.

Clark, R.B. and V.C. Baligar. 2000. Acidic and alkaline soil constrains on plant mineral nutrition, p. 133-177. In: Wilkinson, R.E.(ed.). Plant environment interactions. 2nd ed., Marcel Dekker, Inc., New York, USA.

Eom, K.C., E.U. Son, and S.H. Yoo. 1983. Fertilizer responses of Chinese cabbage to soil water potential. J. Kor. Soc. Soil Sci. Fer. 16:98-105.

Hillel, D. 1998. Environmental Soil Physics: Fundamentals, Applications, and Environmental Considerations. Academic Press, CA, USA.

Jung, P.K., K.C. Eom, S.K. Ha, Y.S. Zhang, and S.O. Hur. 2009. Assessments of the nutrient losses in the sloped farm land. J. Kor. Soc. Soil Sci. Fer. 42:47-50.
Kreuzwieser, J. and A. Gessler. 2010. Global climate change and tree nutrition: influence of water availability. Tree Physiol. 30: 1221-1234.

Lee, J.H. and C.J. Kim. 2011. Derivation of drought severityduration-frequency curves using drought frequency analysis. J. Kor. Water Res. Assoc. 44(11): 889-902.

Lower, S.S. and C.M. Orians. 2002. Soil nutrients and water availability interact to influence willow growth and chemistry but not leaf beetle performance. Entomol. Exp. Appl. 107: 69-79.

Metwally, S.Y. and A.G. Pollard. 1959. Effects of soil moisture conditions on the uptake of plant nutrients by barley and on the nutrient content of the soil solution. J. Sci. Food Agri. 10(11): 632-636.

Munns, R. 2002. Comparative physiology of salt and water stress. Plant Cell Environ. 25:239-250.

National Institute of Agricultural Science and Technology (NIAST). 2000. Analysis method of soil and plant. NIAST, Suwon, Korea.

Neilsen, G. H., P. B. Hoyt, and D. Neilsen. 1995. Soil changes associated with NP-fertigated and drip irrigated high-density apple orchards. Can. J. Soil. Sci. 75: 307-310.

Oh, D.S. and H.J. Cho. 2001. Establishment on Standard Irrigation Format for Upland Crops. In: Research Report 2000. National Institute of Agricultural Science and Technology, Suwon, Korea.

Oh, S.J., Y.S. Zhang, S.K. Kim, P.K. Jung, and K.H. Jung. 2002. Study on nutrient loss in a sloped upland. In: Research Report 2001. National Institute of Agricultural Science and Technology, Suwon, Korea.

Rural Development Administration (RDA). 2013. Red pepper, RDA, Suwon, Korea.

Rural Development Administration (RDA). 2014. Fertilizer recommendation for crop production. RDA, Suwon, Korea.

Song, K.C, Y.S. Ahn, G.R. Cho, K.C. Eom, and S.H. Ryu. 1992. Determination of water demand of crops, p.97-101. In: Research Report 1991. Institute of Agricultural Technology, Rural Development Administration, Suwon, Korea.

Steduto, P., T.C. Hsiao, E. Fereres, and D. Raes. 2012. Crop yield response to water, FAO, Rome, Italy. 